\title{
Penerapan Metode Reduksi pada Penciptaan Karya Seni Grafis Cetak Tinggi Cukil Kayu Chiaroscuro
}

\author{
M. Sigit Ramadhan \\ Program Studi Kriya, Fakultas Industri Kreatif \\ Universitas Telkom
}

\begin{abstract}
Chiaroscuro is known as one of the lighting principles in the artwork that began to develop during Renaissance in the 15th century. It is considering the light-dark on the objects to be applied into the artwork. In the history of its development, this chiaroscuro principle was applied also in printmaking by Caravaggio and several artists from Germany and Italy. The reduction method has a potential to produce a number of different levels of color values by referring to the layer of light falling on the objects so that the impression of volume and depth made in the printmaking artwork will be more visible. In this study, literature studies and observations are done to analyze chiaroscuro's lighting principles and then tested them in the process of experimentation in order to create printmaking works to demonstrate the potential for the application of reduction methods in woodcut printmaking using chiaroscuro lighting principles. At the end, this research produced technical and visual aspect analysis data from the reduction method used in the process of making print works which could be developing and exploring works and learning materials to be conveyed to the artists and the academic community.
\end{abstract}

Keywords: chiaroscuro, printmaking, xylography, woodcut

\section{PENDAHULUAN}

Keberadaan warna dalam sebuah karya seni memiliki peran yang sangat penting, karena berhubungan dengan sejarah kebudayaan manusia mulai dari masa prasejarah hingga kontemporer saat ini. Dalam bentangan sejarah panjang seni rupa dunia, masa Renaissance merupakan salah satu titik penting dimana seniman mulai memiliki keinginan untuk lebih berekspresi dibandingkan dengan seniman pada masa sebelumnya yang masih berkarya berdasarkan asas-asas yang telah disiapkan atau dipolakan oleh penguasa. Di masa Renaissance, dalam seni lukis nampak sekali perubahan pola berkarya tersebut. Para seniman mulai bereksplorasi dengan warna beserta gejala alam yang berkaitan dengannya seperti cahaya dan sensasi visual yang dihasilkan ketika dituangkan kedalam sebuah karya. 
Warna dihasilkan oleh pantulan cahaya yang terdiri dari berkas sinarsinar yang memiliki panjang gelombang dan frekuensi yang berbeda (Darmaprawira, 2002). Seperti contohnya warna merah yang memiliki panjang gelombang paling panjang sekitar 630-720 nm dengan frekuensi paling rendah sekitar 430$480 \mathrm{THz}$ dibandingkan dengan warna lainnya. Selain warna merah terdapat enam warna lain yang memiliki gelombang dan frekuensi yang dapat ditangkap oleh mata manusia diantaranya adalah jingga, kuning, hijau, biru, nila (indigo), dan ungu. Ketujuh warna tersebut merupakan spektrum warna yang dipublikasikan oleh Sir Isaac Newton pada tahun 1672 setelah melakukan percobaan membiaskan cahaya matahari melalui prisma kaca dan memproyeksikannya ke permukaan layar sehingga tampaklah ketujuh susunan warna pelangi tersebut (Fara, 2015).

Warna memiliki nilai atau value yang merupakan tingkatan atau kecerahan suatu warna (Darmaprawira, 2002). Nilai tersebut akan membedakan kualitas tingkat kecerahan suatu warna, sehingga didapat misalnya merah tua yang lebih gelap dan merah muda yang lebih terang dibandingkan warna merah murni. Nilai warna tersebut menunjukan banyaknya intensitas cahaya yang mempengaruhi suatu warna. Hal inilah yang menjadi salah satu pegangan para seniman Renaissance abad-15 yang banyak membuat karya dengan prinsip chiaroscuro. Chiaroscuro sangat mempertimbangkan gelap-terang untuk memberikan kesan volume dan kedalaman suatu objek dalam sebuah karya, sehingga dengan kata lain seniman perlu memiliki kepekaan terhadap nilai warna yang terdapat pada objek untuk divisualisasikan pada karya yang dibuatnya. Nilai warna menjadi salah satu unsur rupa yang cukup penting bagi karya di masa Renaissance, karena permainan gelap-terang tersebut menjadi penguat kesan dramatis yang menjadi intensi visual seniman disamping eksplorasi gestur figur manusia yang menjadi objek karya masa itu.

Beberapa seniman Old Master seperti Caravaggio, Leonardo da Vinci, dan Rembrandt van Rijn menerapkan prinsip chiaroscuro ini pada sebagian besar karya lukisnya. Selain pada karya lukis Caravaggio mengaplikasikan prinsip pencahayaan ini pada karya seni cetak grafis. Perkembangan karya seni grafis chiaroscuro cukup signifikan di awal abad ke-16 di Jerman dan Italia terutama pada jenis seni grafis cetak tinggi teknik cukil dan grafir pada material kayu (Eskerdjian, 2014). Lucas Cranach dan Hans Burgkmair mengawali perkembangannya di Jerman melalui karya cukil kayu chiaroscuro berjudul 'St. George and the Dragon'. Meskipun memiliki judul dan objek utama karya yang sama, namun visual dua karya tersebut cenderung berbeda dikarenakan material terutama teknis kedua seniman tersebut memiliki kekhasan masing-masing. Di Italia karya seni grafis cukil kayu chiaroscuro 
dipopulerkan oleh Ugo da Carpi melalui karya yang dibuat tahun 1516 berjudul 'St. Jerome'. Secara visual prinsip pencahayaan chiaroscuro pada karya Ugo da Carpi lebih terlihat jelas dibandingkan dengan karya Cranach maupun Burgkmair. Pemanfaatan value atau nilai warna yang lebih banyak menjadi salah satu faktor yang menonjol selain image gestur objek karya yang lebih dinamis dibandingkan karya kedua seniman Jerman tersebut.

Secara umum apabila merunut dari kesejarahannya hingga yang sekarang banyak digunakan, metode multiblock digunakan dalam proses pembuatan karya seni grafis berwarna dimana seniman menggunakan dua atau lebih matriks cetak untuk menghasilkan warna yang berbeda dalam sebuah karya seni grafis. Dengan menggunakan metode multi-block seniman dapat membuat matriks yang akan digunakan secara serempak yang otomatis akan mempersingkat waktu pengerjaan. Namun pada sisi lain, metode multi-block memiliki kekurangan dalam hal efisiensi penggunaan material karena memerlukan papan kayu yang cukup banyak sesuai dengan warna yang ingin dihasilkan dan dalam proses pencetakan matriks seringkali dihadapkan pada ketidaksesuaian hasil cetak antar matriks cetak karena perbedaan ukuran atau adanya pergeseran posisi pada saat pencetakan.
Selain multi-block terdapat metode lain dalam proses pembuatan karya cukil kayu berwarna yaitu metode reduksi atau dikenal juga dengan sebutan metode cukil habis. Pada metode ini hanya satu buah bilah papan kayu yang digunakan sebagai matriks cetak, namun dapat menghasilkan warna dengan jumlah yang relatif sama dengan metode multi-block. Jumlah warna yang dihasilkan pada metode ini sesuai dengan tahapan proses pencukilan dan pencetakan yang dilakukan pada satu bilah papan tersebut. Misalkan setelah pencetakan warna pertama, sebelum menghasilkan warna kedua seniman perlu mencukil terlebih dahulu bagian papan yang akan dibiarkan tetap berwarna pertama, begitupun selanjutnya untuk menghasilkan warna ketiga dan seterusnya.

Eksperimen penelitian ini menerapkan metode reduksi dalam proses pembuatan karya seni grafis cetak tinggi cukil kayu chiaroscuro. Sebagai hipotesa awal ragam tingkatan nilai warna yang menjadi ciri khas chiaroscuro dapat dihasilkan oleh jumlah warna dari tahapan cukilcetak yang dilakukan. Untuk memperdalam pemahaman proses sebelumnya dilakukan analisa terhadap prinsip pencahayaan chiaroscuro terkait dengan karkteristik gelap-terang yang dimiliki. Proses pembuatan karya seni grafis cetak tinggi cukil kayu dengan metode reduksi akan diuraikan lebih lanjut untuk menghasilkan data analisa aspek teknis serta visual dari metode 
yang digunakan pada proses pembuatan karya yang dapat menjadi bahan materi pengembangan dan eksplorasi karya.

\section{METODE PENELITIAN}

Penelitian yang dilakukan mengacu pada metode kualitatif berdasarkan analisa dari kajian literatur dan hasil observasi serta eksperimen yang berkaitan dengan penelitian. Kajian literatur dilakukan terhadap objek penelitian yaitu mengenai prinsip pencahayaan chiaroscuro pada sebuah karya seni yang kemudian dilakukan analisa untuk kemudian diambil beberapa temuan penting yang relevan. Observasi langsung pada karya-karya seni grafis dilakukan untuk mengamati potensi penerapan prinsip chiaroscuro yang akan diaplikasikan pada karya seni grafis cukil kayu dengan metode reduksi. Temuan-temuan pada tahap kajian literatur dan observasi kemudian diujikan dalam proses eksperimen proses penciptaan karya untuk menunjukkan potensi penerapan metode reduksi pada karya seni grafis cukil kayu yang menggunakan prinsip pencahayaan chiaroscuro. Hasil akhir dari penelitian ini berupa kesimpulan atas objek penelitian berdasarkan rangkaian proses yang telah dilakukan.

\section{STUDI PUSTAKA}

\section{Nilai warna (Value)}

Albert Munsell (dalam Darmaprawira, 2002) berpendapat bahwa warna memiliki tiga dimensi, berupa warna yang tersusun dari hasil campuran hitam putih sebagai porosnya, lingkaran warna melingkari poros, dan skala warna bergerak menuju poros. Untuk mengetahui suatu hubungan warna perlu dikenal kualitas warna, sebab untuk mengetahui skala warna biru misalnya tidak cukup hanya menyebutkan warna biru tua dan biru muda saja, sebab perlu kejelasan setua apa atau semuda apa warna biru tersebut. Albert Munsell pada 1912 menemukan sistem pengorganisasian warna yang sistematik beserta terminologinya, yang kemudian disebut dengan Sistem Munsell. Sistem Munsell dapat memberikan petunjuk untuk skala pembatasan kualitas warna dengan interval untuk tujuan perancangan secara skematis.

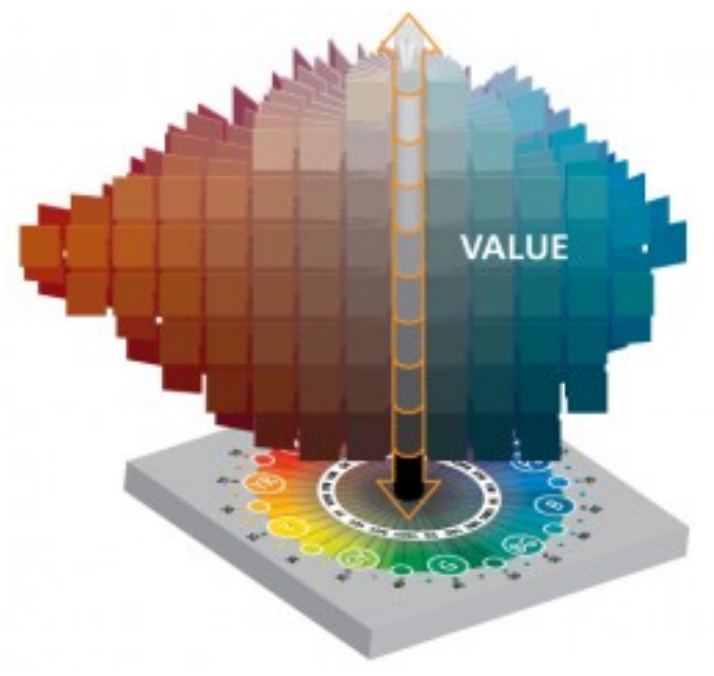

Gambar 1. Diagram nilai warna Sistem Munsell. Sumber: http://munsell.com/ about-munsellcolor/how-color-notation-works/munsell-value/, diakses pada 22 Juni 2018

Nilai warna merupakan dimensi kedua dari tiga dimensi warna versi Sistem Munsell, dimana dimensi pertama merupakan nama warna dan dimensi ketiga adalah intensitas 
warna. Nilai warna merupakan tingkatan atau urutan kecerahan suatu warna dimana nilai tersebut akan membedakan misalnya warna merah merah murni dengan warna merah tua yang lebih gelap atau merah muda yang lebih terang. Secara teoritis, diagram tingkatan nilai warna dibagi menjadi sembilan tingkat, dengan warna hitam yang tergelap, melalui deretan warna abuabu hingga warna putih yang memiliki warna tercerah.

Warna putih memiliki nilai warna tertinggi, sedangkan warna hitam memiliki nilai warna terendah. Dalam pencampuran warna bila warna ingin dibuat lebih terang dapat menambahkan warna putih, sebaliknya apabila warna ingin dibuat lebih gelap dapat menambahkan warna hitam, dengan kata lain setiap warna dapat dirubah nilainya.

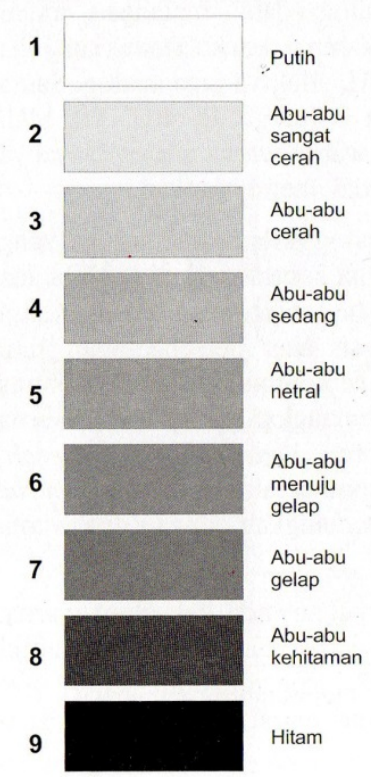

Gambar 2. Skema susunan nilai. Sumber: Darmaprawira (2002)
Warna abu-abu (nomor 5) merupakan warna paling netral. Deretan nilai diatas warna abu-abu tersebut memiliki nilai tinggi, sedangkan deretan warna dibawahnya memiliki nilai rendah.

Peneliti Faber Birren membuat sebuah skema tiga tingkat kecerahan warna yang memetakan warna-warna yang dihasilkan berdasarkan hubungan dari tiga unsur utama yang mempengaruhi nilai suatu warna. Ketiga unsur utama tersebut merupakan warna murni (hue) yang ditempatkan pada bagian kiri, warna putih pada bagian kanan atas dan hitam pada bagian kanan bawah.

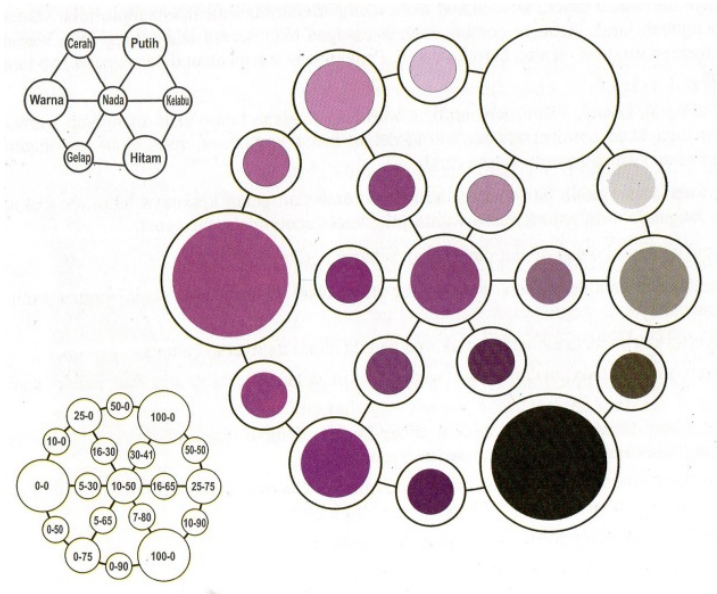

Gambar 3. Skema nilai warna oleh Faber Birren. Sumber: Darmaprawira (2002)

Pencampuran warna murni dengan putih, abu-abu dan hitam akan menghasilkan tiga macam tingkat kecerahan atau nilai warna, yaitu yang dinamakan deretan warna cerah atau tints, deretan warna nada atau tones, dan deretan warna gelap atau shades (Darmaprawira, 2002).

\section{Seni Grafis}


Seni grafis merupakan salah satu cabang seni rupa yang dalam proses pembuatan karyanya dilakukan dengan teknik mencetak negatif atau matriks cetak pada sebuah bidang. Seperti cabang seni rupa lainnya, seni grafis secara sadar menggunakan keterampilan dan kreativitas untuk menciptakan karya yang estetik. Terdapat empat kategori teknik yang ada pada seni grafis sesuai dengan proses pencetakannya, diantaranya adalah cetak tinggi (relief print), cetak dalam (intaglio), cetak datar (planography), dan cetak saring (serigraphy).

Karya seni grafis dibangun dari beberapa aspek integral yang mengkonstruksi keutuhan presentasi karya, aspek tema yang melatar belakangi, aspek estetik yang menghiasi dan aspek teknik yang mengeksekusi. Ketiga aspek tersebut saling memengaruhi dan mendukung sehingga akan menghasilkan karya seni yang solid.

Seni grafis Indonesia mulai dikenal oleh dunia pada tahun 1946 melalui proyek yang dikerjakan oleh Mochtar Apin dan Baharuddin Marasutan atas tugas "Oeroesan Pemoeda Perhoeboengan Loear Negeri" yang merupakan bagian dari Sekretariat Negara dalam rangka memperingati hari kemerdekaan Indonesia yang pertama. Karya Mochtar Apin berjudul "Arak-arakan", menampilkan gambaran barisan orang membawa spanduk bertuliskan "sekali merdeka tetap merdeka". Sedangkan Baharuddin Marasutan menampilkan sisi humanis sosok bangsa yang baru merdeka lewat karya "Hidup Sunyi", dengan gambar sebuah pot tanaman hias teronggok di pojokan. Menurut Aminuddin T.H. Siregar melalui tulisannya dalam Katalog Pameran Seni Grafis, dari Cukil sampai Stensil, proyek seni grafis 1946 merupakan peristiwa yang bakal merintis perkembangan seni grafis Indonesia, namun sulit dianggap sebagai peristiwa yang melahirkan sebuah kesadaran tentang otonomi seni grafis itu sendiri (Bentara Budaya Jakarta, 2007).

\section{Seni Grafis Cetak Tinggi Cukil Kayu Chiaroscuro}

Chiaroscuro berasal dari bahasa Italia chiaro (terang) dan oscuro (gelap), dapat juga diartikan menjadi kontras yang sangat kuat antara cahaya dan bayangan dalam suatu karya seni. Chiaroscuro mempertimbangkan jatuhan cahaya pada objek karya yang memberikan kesan trimatra sangat jelas akibat pengaplikasian highlights dan shade. Selain diterapkan pada karya seni lukis, pada masa Renaissance abad ke-16 prinsip pencahayaan ini banyak pula diterapkan pada karya seni grafis oleh para seniman di masa itu. 


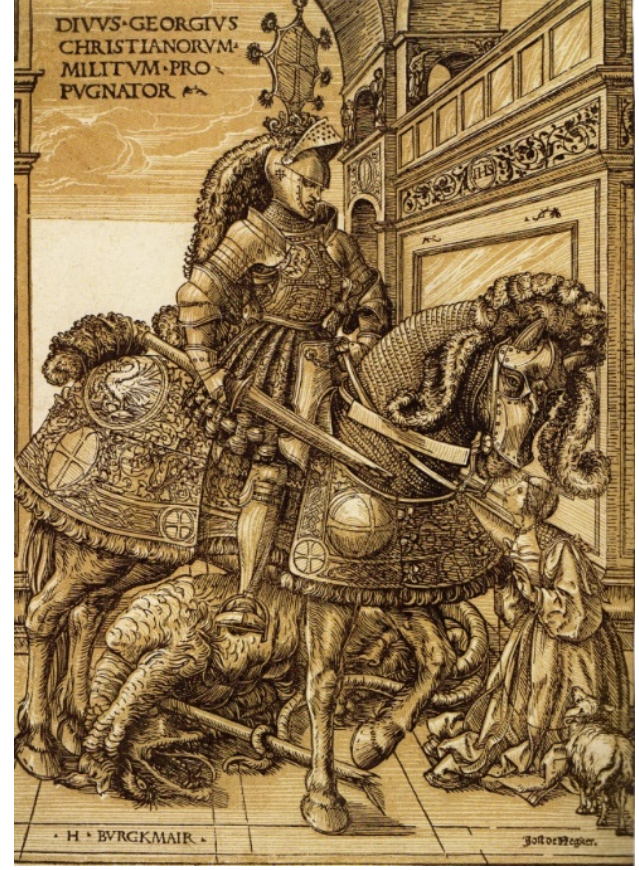

Gambar 4. 'St. George and the Dragon' karya seni grafis cetak tinggi cukil kayu chiaroscuro oleh Hans Burgkmair yang dibuat tahun 1508. Sumber: Eskerdjian (2014)

Seni grafis cukil kayu chiaroscuro merupakan seni grafis cukil kayu berwarna yang memiliki gradasi tingkatan warna untuk menunjukan adanya volume dan kedalaman. Jenis karya ini dibuat dengan cara mencetak dua atau lebih bilah papan kayu di atas masing-masing hasil cetakan (Eskerdjian, 2014). Secara umum, apabila merunut dari kesejarahannya hingga yang sekarang banyak digunakan, proses pembuatan karya seni grafis cetak tinggi cukil kayu chiaroscuro dibuat dengan metode multi-block dimana seniman menggunakan dua atau lebih papan kayu sebagai cetakan untuk menghasilkan tingkatan warna yang berbeda dalam karya. Terdapat dua istilah untuk menamai papan kayu yang digunakan dalam proses cetak. Pertama yaitu 'line block', merupakan matriks cetak yang berisi garis tepi dari image yang ingin dihasilkan. Istilah kedua yaitu 'tone block' atau 'colour block', merupakan matriks cetak yang berisi bidang warna dari image yang ingin dihasilkan. Biasanya lebih dari satu 'tone block' digunakan untuk mencetak bidang warna dengan tingkatan yang berbeda.

Image yang akan dicetak biasanya dibuat menjadi sebuah gambar terlebih dahulu sebelum akhirnya dipindahkan pada bilah papan kayu. Namun adakalanya seniman membuat image langsung pada papan kayu yang akan digunakan. Seperti pada teknik seni grafis lainnya, dalam cetak tinggi cukil kayu chiaroscuro ini image yang dibuat sebagai matriks akan muncul terbalik (reversed) setelah dicetak pada media cetaknya.

Giorgio Vasari, merupakan seorang seniman yang juga sejarawan seni Italia pertama yang memaparkan metode multi-block ini secara mendetail (Eskerdjian, 2014). Dalam pembahasan teknisnya, Vasari merekomendasikan bahwa bilah papan pertama yang dibuat sebagai matriks adalah 'line block' terlebih dahulu, kemudian hasil cetak dari 'line block' tersebut dicetakkan pada bilah papan kedua untuk mereproduksi garis dalam rangka membantu menghasilkan 'tone block'. Lanjut Vasari, cat putih dapat digunakan pada bilah papan kedua untuk menandai bidang yang menjadi highlights. Bidang ini yang kemudian dicukil dan akan tetap menjadi putih 
setelah dicetak. Langkah tersebut dapat digunakan untuk menghasilkan 'tone blocks' selanjutnya. Dalam proses pencetakan bilah-bilah papan dicetak dengan urutan terbalik dengan proses pencukilan. Matriks dengan warna paling terang, yaitu bilah papan yang dicukil untuk menghasilkan highlights dicetak terlebih dahulu disusul kemudian matriks yang menghasilkan warna lebih gelap, dan terakhir 'line block' yang menghasilkan garis tepi dari image yang dihasilkan. Setiap matriks harus dicetak dalam posisi yang selaras untuk menghindari image akhir yang kabur ataupun adanya distorsi.

\section{HASIL DAN ANALISA}

\section{Analisa Visual Chiaroscuro}

Chiaroscuro berkaitan dengan penerapan beberapa nilai warna (value) berbeda yang seniman aplikasikan pada karyanya. Perbedaan nilai warna tersebut dipengaruhi oleh besaran intensitas cahaya yang jatuh pada permukaan objek yang menjadi image karya. Perbedaan nilai warna yang divisualisasikan pada karya inilah yang menjadi karakteristik utama dari prinsip pencahayaan chiaroscuro.

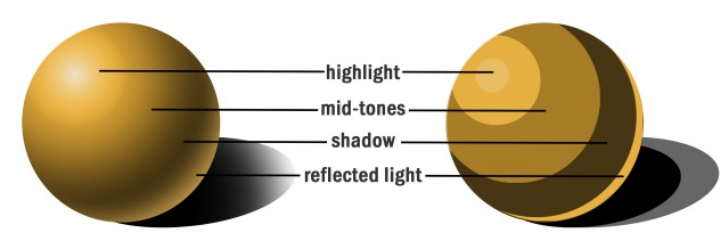

Gambar 5. Ilustrasi pembagian bidang nilai warna sebagai akibat jatuhan cahaya pada benda. Sumber: Dokumentasi Pribadi (2018)
Terdapat setidaknya empat pembagian nilai warna yang diakibatkan oleh cahaya yang jatuh pada objek benda. Cahaya dengan intensitas tinggi (highlight) yang jatuh pada objek mengakibatkan bagian ini divisualkan dengan warna yang memiliki nilai tinggi bahkan cenderung berwarna putih pada bidang karya. Bidang kedua adalah mid-tones yang merupakan bagian dimana warna yang muncul pada objek memiliki nilai yang menengah karena intensitas cahaya yang jatuh pada bagian ini tidak terlalu tinggi ataupun rendah, dengan kata lain warna yang muncul pada bidang ini adalah warna murni (hue) dari objek karya.

Bidang ketiga disebut shadow dimana pada bagian ini memiliki nilai warna lebih rendah sehingga warna yang divisualkan pada objek karya dibuat lebih gelap dibandingkan dengan dua bidang sebelumnya. Semakin kecilnya intensitas cahaya yang menerpa benda maka akan semakin rendah nilai warnanya sehingga warna yang divisualisasikan akan menjadi semakin gelap. Bidang keempat reflected light merupakan bagian dimana benda mendapatkan paparan cahaya yang berasal dari pantulan benda lain disekitarnya. 


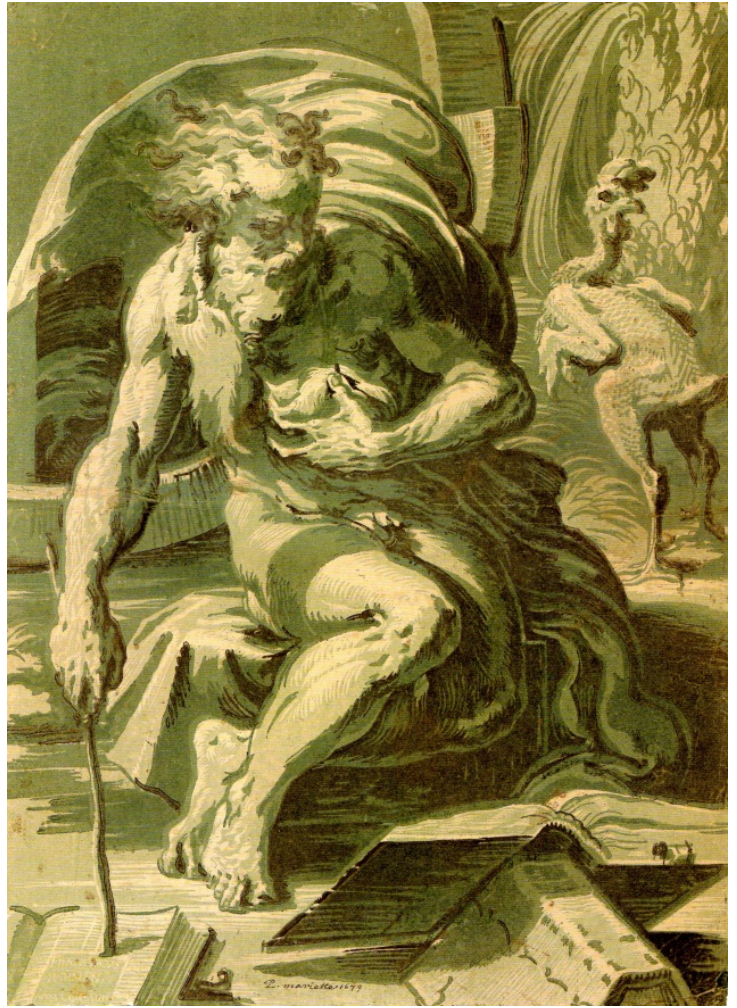

Gambar 6. 'Diogenes' karya seni grafis cetak tinggi cukil kayu chiaroscuro oleh Ugo da Carpi yang dibuat tahun 1527. Sumber: Eskerdjian (2014)

Pembagian keempat bidang nilai warna tersebut menjadi acuan pembagian lapisan warna yang dicetakan pada proses pembuatan karya seni grafis cetak tinggi cukil kayu chiaroscuro dengan menggunakan metode reduksi. Mengacu kepada empat bidang dengan nilai warna yang berbeda tersebut maka jumlah lapisan warna yang dicetakpun akan berjumlah empat lapis, dengan itu berarti seniman memerlukan empat kali proses pencukilan dan pencetakan secara bertahap dalam empat buah bilah yang digunakan sebagai matriks apabila menggunakan metode multiblock atau hanya pada satu buah bilah papan kayu apabila menggunakan metode reduksi.

\section{Metode Reduksi pada Penciptaan Karya Seni Grafis Cetak Tinggi Cukil Kayu Chiaroscuro}

Cukil kayu (woodcut) atau xylography merupakan teknik cetak relief atau cetak tinggi dalam khazanah seni grafis, dimana gambar dihasilkan oleh hasil cetak permukaan papan kayu yang tersisa setelah bagian permukaan yang tidak ingin dicetak mengalami proses pencukilan atau pemahatan. Dalam sejarah perkembangannya, karya seni grafis cukil kayu yang menggunakan prinsip chiaroscuro dibuat dengan metode multi-block. Multi-block terkait dengan jumlah papan kayu yang digunakan untuk membuat karya tersebut. Salah satu metode lain yang dikaji pada penelitian ini adalah metode reduksi yang berpotensi untuk membuat proses penciptaan karya lebih efektif dan efisien terutama dalam hal penggunaan material yang digunakan dan proses pencetakan matriks.

Reduksi merupakan salah satu metode pengerjaan teknik cukil kayu dimana seniman menghasilkan beberapa warna dalam satu karya cetak dengan hanya menggunakan satu matriks (plat cetak). Biasanya dimulai dengan menoreh bagian papan kayu yang merupakan warna paling muda ketika nantinya dicetak, kemudian mencetakkannya ke sejumlah kertas sebagai edisi cetak sebelum papan kayu dibersihkan dari tinta dan dicukil kembali untuk pencetakan warna berikutnya di atas 
warna terakhir. Salah satu kelebihan dari metode ini adalah hasil cetak setiap warna cenderung akan bertumpuk lebih sempurna meskipun dengan kerumitan cukilan yang berbeda di setiap lapisannya karena hanya satu matriks papan kayu yang digunakan sehingga mempermudah mounting pada proses pencetakan. Pada sisi lain metode reduksi ini menyebabkan matriks cetak tidak dapat digunakan kembali untuk mencetak warna sebelumnya dikarenakan permukaan matriks telah berkurang oleh proses pencukilan, namun hal terebut memberikan implikasi terhadap nilai eksklusivitas karya seni grafis yang dibuat secara terbatas.

Tahapan pertama dalam proses pembuatan karya seni grafis cetak tinggi cukil kayu pada umumnya adalah mempersiapkan bilah papan kayu yang akan digunakan sebagai matriks. Papan kayu dapat dihaluskan atau diolah kembali untuk menghasilkan efek tertentu sesuai dengan tujuan seniman. Setelah dihaluskan papan kayu dapat diberi lapisan cat dasar untuk mengurangi terjadinya penyerapan tinta pada papan kayu saat proses pencetakan nanti.

Proses pembuatan sketsa dapat dilakukan secara langsung pada papan kayu ataupun dengan memindahkan sketsa dari kertas lain dengan cara transfer menggunakan cairan alkohol, aseton atau soulvent sebelum melakukan proses pencukilan. Selanjutnya setelah dicukil, matriks dapat dicetak dalam jumlah tertentu sesuai dengan edisi yang ingin dihasilkan.

Untuk dapat lebih memahami dan menggali lebih dalam potensi penerapannya, penulis melakukan eksperimen dengan membuat satu seri karya seni grafis cetak tinggi cukil kayu chiaroscuro dengan menggunakan metode reduksi. Berikut sketsa yang akan dibuat menjadi karya seni grafis:

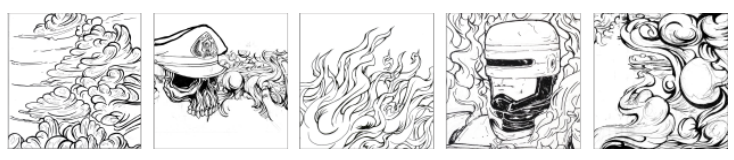

Gambar 7. Sketsa yang akan dibuat menjadi karya seni grafis cetak tinggi cukil kayu chiaroscuro. Sumber: Dokumentasi Pribadi (2016)

Sketsa karya yang dibuat kemudian dipindahkan pada bilah papan kayu yang sudah diberi lapisan cat dasar dengan cara transfer menggunakan cairan bensin.

Dalam proses pembuatan karya seni grafis cukil kayu dengan metode reduksi. Tahapan pencukilan dan pencetakan dilakukan beberapa kali dengan menggunakan bilah papan kayu yang sama hingga dihasilkan warna yang beragam sesuai dengan yang diinginkan. Untuk menghasilkan karya grafis yang menerapkan metode pencahayaan chiaroscuro, proses pencukilan matriks dilakukan dalam rangka mengasilkan warna dengan tingkat kecerahan atau nilai yang beragam setelah dicetak pada kertas. Setelah proses pencukilan, sebelum memasuki tahap pencetakan terlebih dahulu penulis 
menentukan skema warna yang akan diaplikasikan dengan mengacu kepada teori nilai warna yang telah dianalisa sebelumnya.

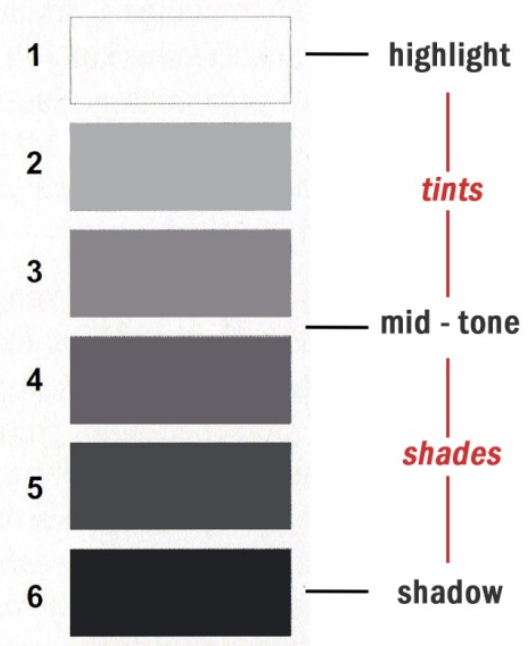

Gambar 8. Skema warna yang akan diaplikasikan pada karya seni grafis cetak tinggi cukil kayu chiaroscuro. Sumber: Dokumentasi Pribadi (2018)

Berdasarkan skema warna yang dibuat diperoleh warna abu kebiruan yang akan diaplikasikan dengan lima tingkatan nilai warna yang berbeda. Dengan demikian proses reduksi papan matriks dilakukan sebanyak lima kali proses pencukilan.

Begitu pula dengan proses pencetakan yang akan dilakukan sebanyak lima kali dengan mengaplikasikan warna yang telah ditentukan pada setiap tahapannya. Berikut penulis tampilkan urutan proses pencetakan matriks dalam tabel bersama dengan hasil cetaknya pada kertas.

Tabel 1. Tahapan proses cetak matriks pada media kertas

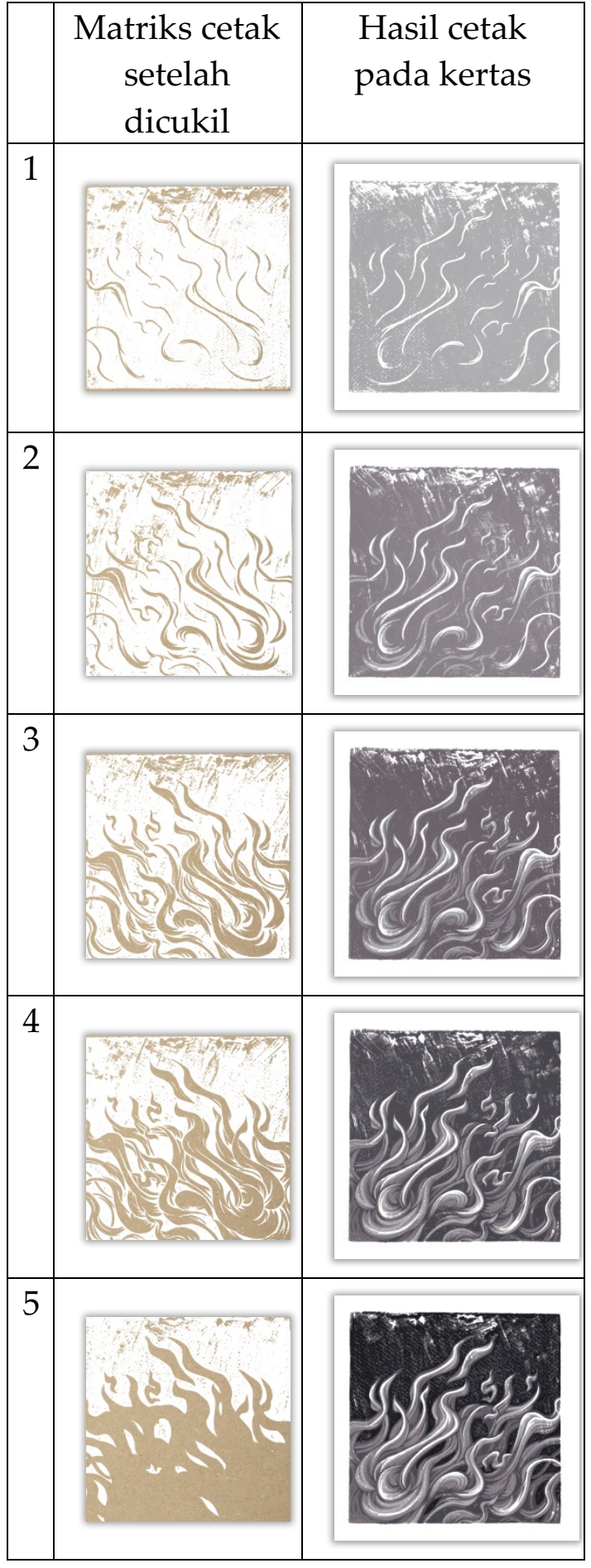

Hasil analisa dari eksperimen proses cetak dengan metode reduksi yang dilakukan dapat terlihat bahwa dari segi visual dengan menggunakan matriks yang sama konsistensi perpindahan tingkat nilai warna dapat terlihat dengan jelas dan mudah dihasilkan sehingga semakin 
memperkuat karakter chiaroscuro pada karya yang dibuat. Sedangkan dari segi teknis proses cetak setiap tingkatan nilai warna dapat dilakukan dengan hasil yang lebih presisi karena menggunakan satu buah matriks yang sama dengan proses pencukilan reduktif sesuai dengan jumlah tingkatan nilai warna yang ingin dihasilkan.

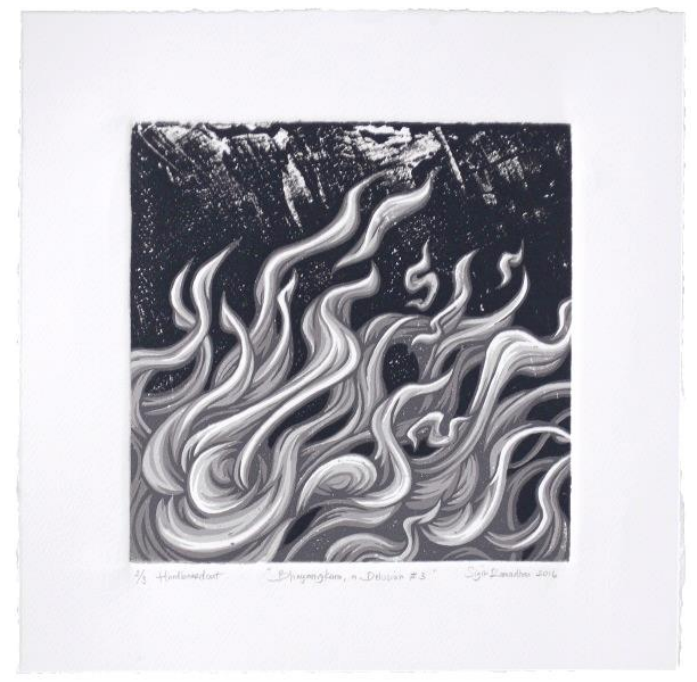

Gambar 9. Salah satu karya seni grafis cetak tinggi cukil kayu chiaroscuro penulis dari seri 'Bhayangkara, A Delusion' yang dibuat menggunakan metode reduksi dengan enam tingkatan nilai warna. Sumber: Dokumentasi Pribadi (2016)

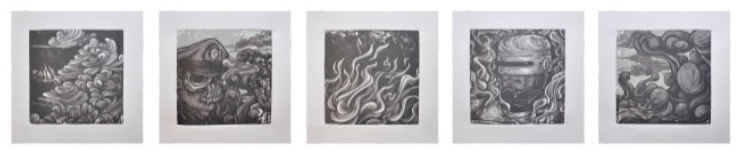

Gambar 10. 'Bhayangkara, A Delusion' seri karya seni grafis cetak tinggi cukil kayu yang dibuat menggunakan metode reduksi dengan enam tingkatan nilai warna. Sumber: Dokumentasi Pribadi (2016)

\section{KESIMPULAN}

Warna memiliki nilai atau value yang membedakan kualitas tingkat kecerahan suatu warna, sehingga didapat misalnya merah tua yang lebih gelap dan merah muda yang lebih terang dibandingkan warna merah murni. Nilai warna tersebut menunjukan banyaknya intensitas cahaya yang mempengaruhi suatu warna. Hal inilah yang menjadi salah satu pegangan para seniman Renaissance abad-15 yang banyak membuat karya dengan prinsip chiaroscuro. Chiaroscuro sangat mempertimbangkan gelap-terang untuk memberikan kesan volume dan kedalaman suatu objek dalam sebuah karya, sehingga dengan kata lain seniman perlu kepekaan terhadap nilai warna yang terdapat pada objek untuk divisualisasikan pada karya yang dibuatnya. Selain pada seni lukis, dalam sejarah perkembangannya prinsip chiaroscuro ini diaplikasikan juga dalam seni cetak grafis oleh beberapa seniman yang berasal dari Jerman dan Italia.

Selain metode multi-block yang umum digunakan untuk menghasilkan karya grafis berwarna, metode reduksi memiliki potensi untuk menghasilkan visual chiaroscuro pada karya seni grafis cetak tinggi cukil kayu salah satunya dikarenakan adanya relevansi antara penggunaan tingkatan kecerahan (nilai) warna pada karya chiaroscuro yang dapat dibuat dengan tingkatan lapisan cetak pada metode reduksi. Proses penciptaan karya lebih efektif dan efisien terutama dalam hal penggunaan material yang digunakan dan proses pencetakan matriks menjadi keunggulan metode ini dibandingkan dengan metode multiblock. Hasil cetak setiap warna 
cenderung akan bertumpuk lebih presisi sempurna meskipun dengan kerumitan cukilan yang berbeda di setiap lapisannya karena hanya satu matriks papan kayu yang digunakan sehingga mempermudah mounting pada proses pencetakan.

Pada sisi lain metode reduksi ini menyebabkan matriks cetak tidak dapat digunakan kembali untuk mencetak warna sebelumnya dikarenakan permukaan matriks telah berkurang oleh proses pencukilan, namun hal terebut memberikan implikasi terhadap nilai eksklusivitas karya seni grafis yang dibuat secara terbatas.

\section{DAFTAR PUSTAKA}

Bentara Budaya Jakarta. 2007. Seni grafis, dari cukil sampai stensil. Penerbit Bentara Budaya, Jakarta.

Buckland, Jean - Wright. 1973. Etching and Engraving, Techniques and Modern Trend. Dover Publication, Inc., New York.

Darmaprawira W. A., Sulasmi. 2002. Warna: Teori dan Kreativitas Penggunaannya, Penerbit ITB, Bandung.

Fara, Patricia. 2015. Newton Shows The Light: A Commentary on Newton
(1672) 'A letter ... Containing His

New Theory About Light and Colours...'. Phil. Trans. R. Soc. A 373: 20140213.

http://dx.doi.org/10.1098/rsta.2 014.0213

Eskerdjian, David. 2014. CHIAROSCURO: Renaissance Woodcuts from Collections of Georg Baselitz and The Albertina, Vienna. Royal Academy of Arts, London.

Hughes, Ann d'Arcy \& Morris, Hebe Vernon. 2008. PRINTMAKING Traditional and Contemporary Techniques. RotoVision SA, Switzerland.

Morenus, Linda Stuber, dkk. 2015. 16TH- AND 17TH-CENTURY ITALIAN CHIAROSCURO WOODCUTS:

INSTRUMENTAL ANALYSIS, DEGRADATION, AND CONSERVATION, Journal of the American Institute for Conservation, 54:4, 238-271.

Ramadhan, M.S. \& Siregar, A. 2017. Bhayangkara (Tafsir Visual Peristiwa Sejarah Perang Bubat). Journal of Visual Art and Design, 9(1), 14-27. doi:10.5614/j.vad.2017.9.1.2 